\title{
PROTECTION AGAINST RUGGLE BY BIOHERBICIDES, HERBICIDES AND MECHANICAL METHODS
}

\author{
Pölös Endre1", Palkovics András1, Szabó Csaba1, Tatjana Duric2, Hóman Zoltán1,Tóth Horgosi \\ Péter1 \\ ${ }^{1}$ Department of Horticulture, Faculty of Horticulture and Rural Development, János Neumann \\ University, Hungary \\ ${ }^{2}$ Autonomous Province of Vojvodina, Republic of Serbia, Újvidék \\ https://doi.org/10.47833/2020.2.AGR.016
}

\section{Keywords: \\ ragweed \\ plant ecosystem \\ bio-herbicide \\ ecotoxicology \\ herbicide}

\section{Article history:}

Received 20 Feb 2020

Revised 19 March 2020

Accepted 25 March 2020

\begin{abstract}
A bio-herbicide kills ragweed like a classic herbicide. After an environmentally friendly treatment with bio-herbicide the original ecosystems would be restored more easily. The bio-herbicide conserves natural fauna. After mechanical control, the plant should sprout again and the treatment should be repeated at least three times. The economic aspects are the subject of further investigation.
\end{abstract}

\section{Introduction}

The common ragweed (Ambrosia artemisiifolia L.; Asteraceae) is a North American native that is invading Eurasia [1,3]. Besides its economic impact on crop yield, it presents a major health problem because of its highly allergenic pollen [2, 4, 6]. Our herbicide experiment was primarily directed against Ambrosia artemisiifolia. It was invented using a biological method using a bioherbicide containing a biologicalagent (in this case a plant active ingredient). The effect of this bioherbicide is based on the fact that it contains allelochemicals which have growth, developmental and germinating properties $[3,5]$. The organic spray was applied with a back sprayer.

\section{Method}

\section{Defense was done on the green area of Kecskemét}

The weed survey was taken in the morning of 15.07.2018, the results of which are shown in Table 1. Before the treatment of ragweed, it was in a 15-leaf phenological stage, and the average height of the measured specimens reached $20 \mathrm{~cm}$.

Table 1: Plant composition of the experimental area

\begin{tabular}{|l|c|c|}
\hline \multicolumn{1}{|c|}{ Scientific name } & Coverage (\%) & $\begin{array}{c}\text { Abundace - } \\
\text { Dominance value } \\
\%\end{array}$ \\
\hline Ambrosia artemisifolia & 30 & 3 \\
\hline Lactuca serriola & 20 & 2 \\
\hline Conyza canadensis & 10 & $1-2$ \\
\hline Chenopodium album & 10 & $1-2$ \\
\hline
\end{tabular}

\footnotetext{
*Corresponding author. E-mail address: polos.endre@kvk.uni-neumann.hu
} 


\begin{tabular}{|l|l|l|}
\hline Cynodon dactylon & 5 & 1 \\
\hline Melandrium album & 5 & 1 \\
\hline Tribulus terrestris & 5 & 1 \\
\hline
\end{tabular}

\subsection{Effect of bioherbicide on ragweed and its comparison with conventional herbicide}

The experimental area $\left(600 \mathrm{~m}^{2}\right)$ contained a total of 1227 ragweed specimens. The treatment was performed twice in total. The first spraying took place on Tuesday, 11.08.2018 from 9:00am to 11:00am. The average temperature in the morning was $27^{\circ} \mathrm{C}$. By day 0 , ragweed leaves had become yellow and many individuals had already developed necrotic drying spots (Fig.1). The second bioherbicide treatment was performed one week later, on Tuesday, August 18, 2018 from 9:30am to 12:00am. It was very cloudy, gusty weather, with moderate air movement and drizzling rain ( $2 \mathrm{~mm}$ rainfall) with an average temperature of $22^{\circ} \mathrm{C}$. Ragweed blooms had already begun, with an average height of $22 \mathrm{~cm}$ and an average of 25 leaves. On the 4th day after the second treatment, $91.28 \%$ (1120 plants) of the Ambrosia artemisiifolia population were dried up by the organic spray (it means $62.1 \%$ ) completely dried up (Figure 1), 29.18\% were semi-dry. The remaining $8.72 \%$ ragweed specimens (107 strains) remained intact because they were not exposed to the bioherbicide.

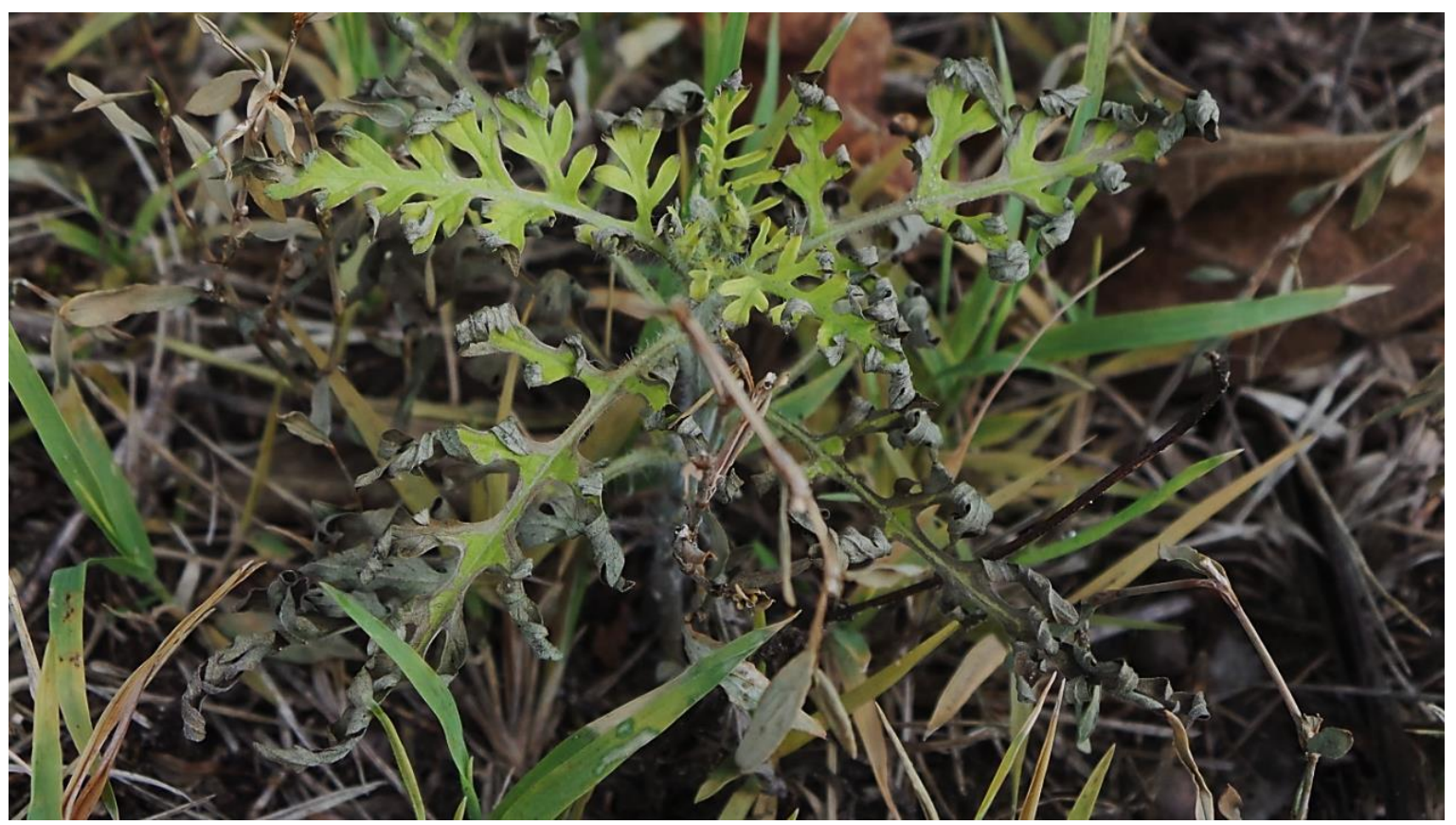

Figure 1. Initial effect of bioherbicide: appearance of necrotic spots on the edges of ragweed leaf

The bio-herbicide showed partial selectivity, as not only ragweed, but also dicotyledonous (Conyza canadensis) appeared to be very sensitive to its effect. As early as 3 days after the first spraying, the infestations of the rabies suffered complete necrotic dehydration. This natural spray has a systemic effect as it is absorbed through the green parts of the plant into the entire plant. It has the advantage over conventional herbicides that it works in a short time (3-4 days).

In contrast to the bioherbicide, Glialka Top, which is also approved in the public domain, is non-selective, as it kills perennial monocotyledonous and dicotyledonous weeds (Fig. 2), especially natural grass lawns. This spray is absorbed into the whole plant through the green part of the plant, but it takes much longer (within 1-2 weeks) before it kills the weeds. 


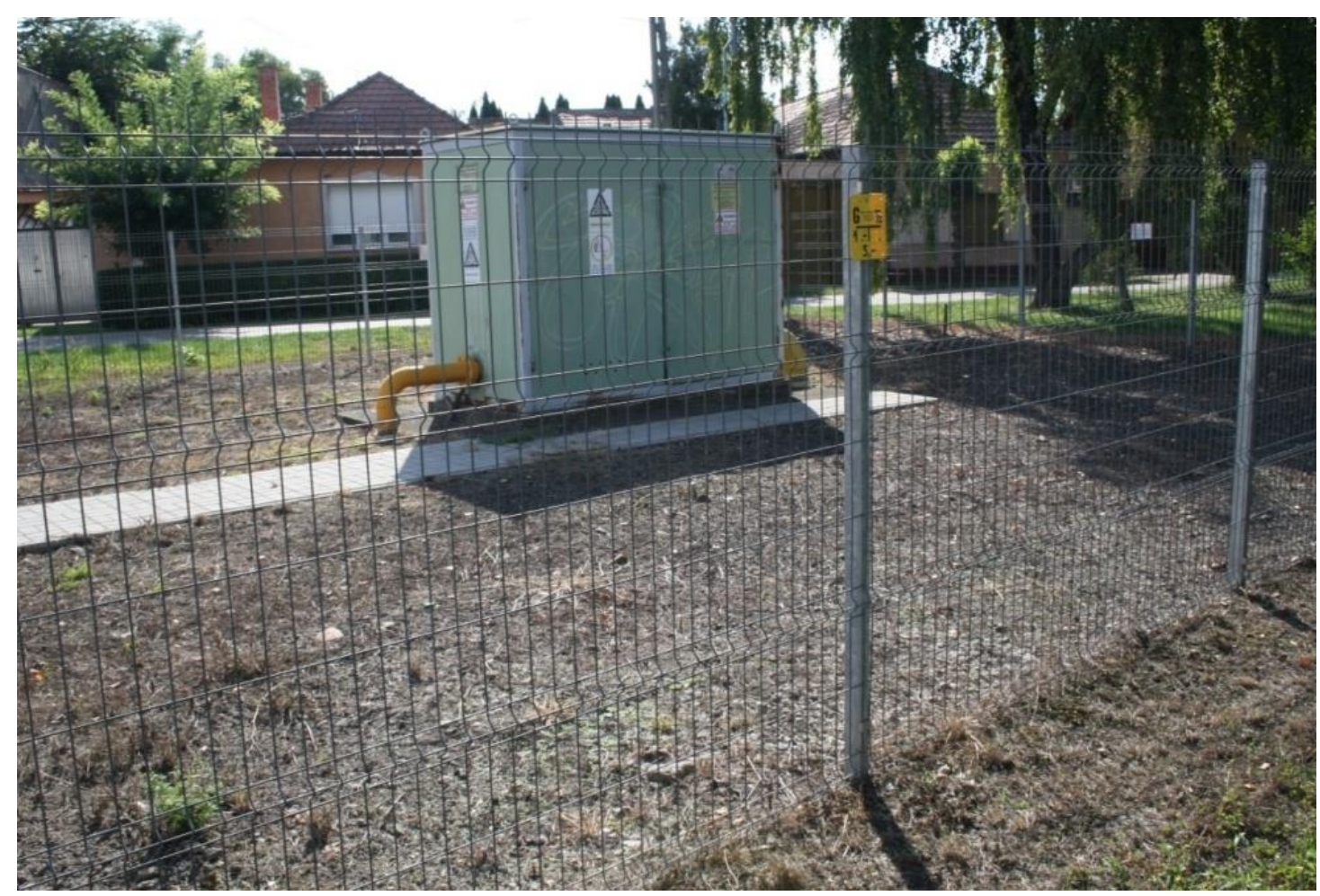

Figure 2. Glialka Top herbicidal effect

In the mowed areas, there is significant recurrence of ragweed and also invasive silkworm. A cut ragweed can grow 10 seedlings and at the same time increase the number of pollen flowers, thereby increasing pollen output (Figure 3. 4).

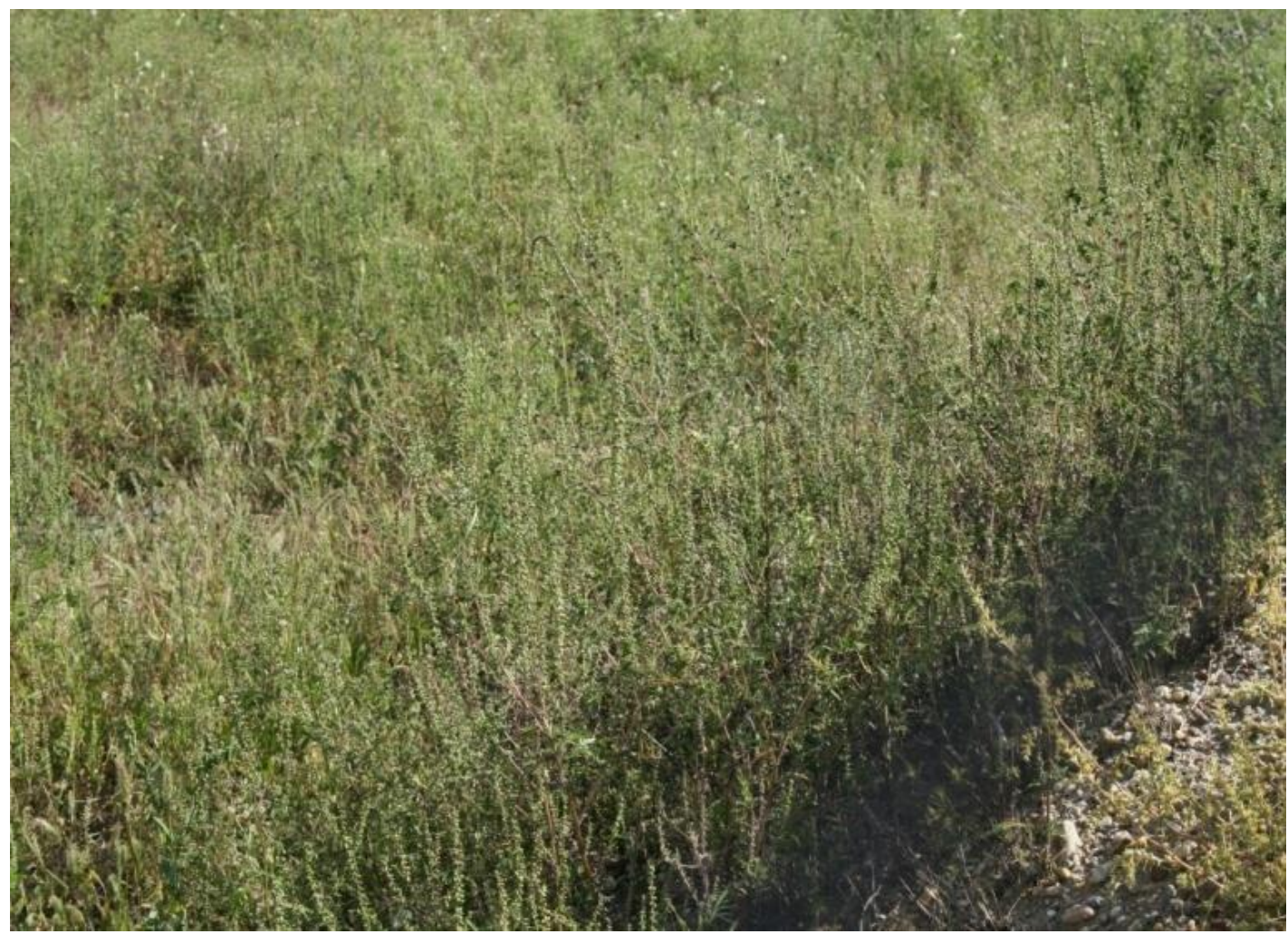

Figure 3. Reproductive ragweed plants 


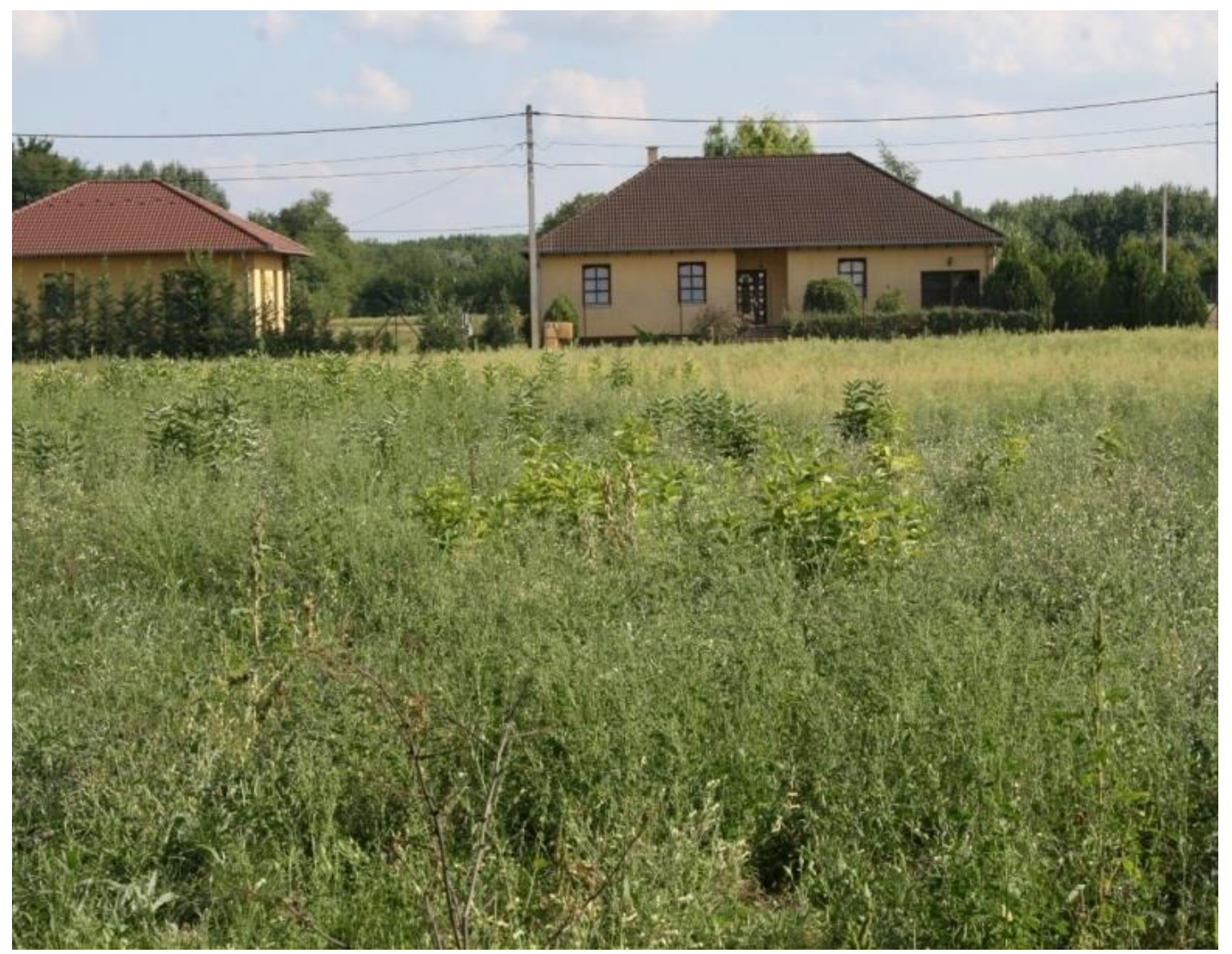

Figure 4. Ragweed and Asclepias syriaca

\subsection{Control of ragweed in the Fülöpház district of the Kiskunság National Park}

The purpose of control is to suppress invasive plant species from natural plant ecosystems. Invasive species in the Kiskunság National Park:

- Ambrosia artemisiifolia

- Asclepias syriaca

- Conyza canadensis

- Solidago canadensis

- Ailanthus altissima

- Robinia pseudo-acacia

We focused on the control of pollen-allergenic ragweed, which is extremely important for human health.

We used three methods:

1. Bio-herbibicides environmentally friendly control

2. Classical herbicide control

3. Mechanical defense by mowing 


\section{Results}

The results of the defense are illustrated in the following figures (Figure 5-8)

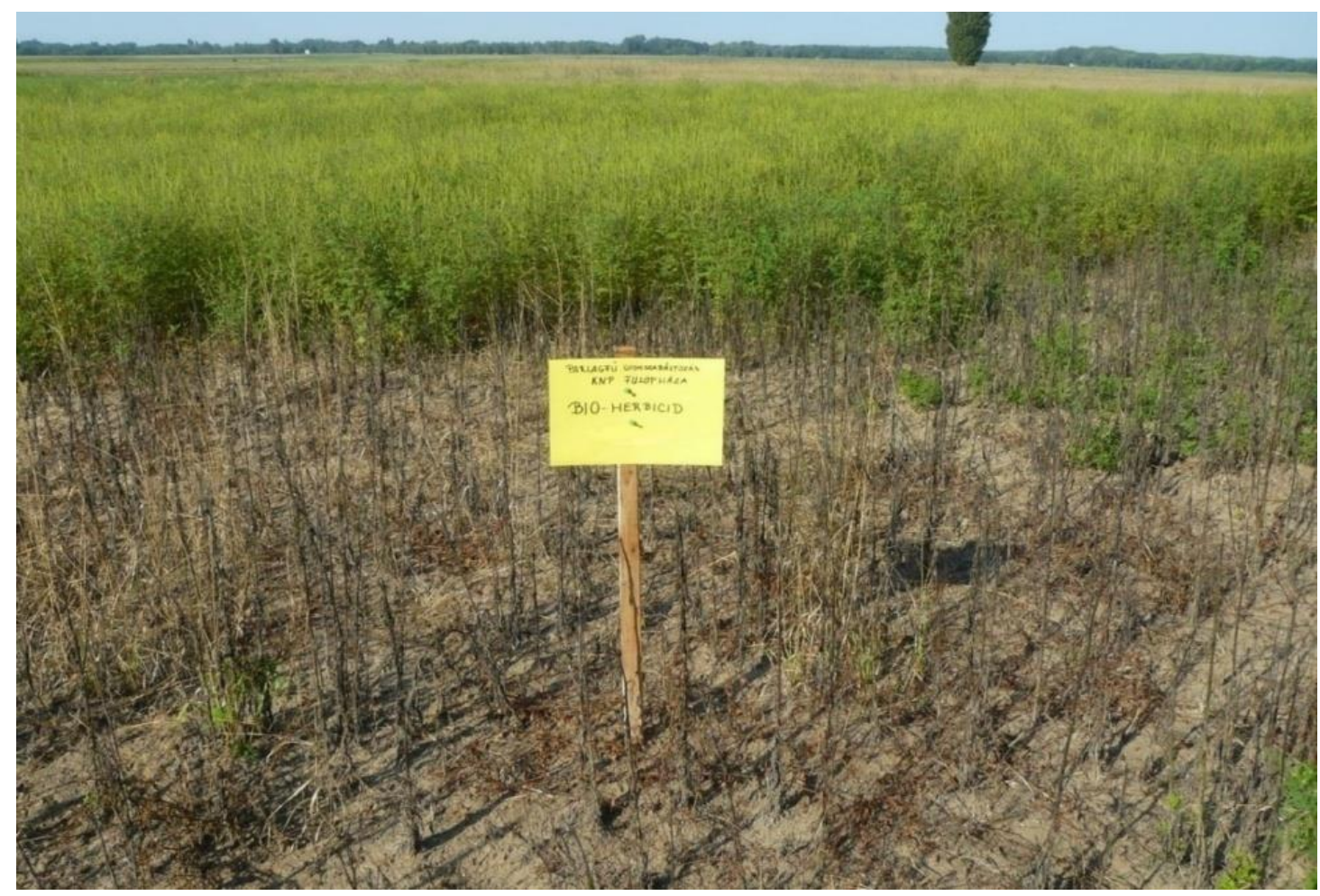

Figure 5. Bio-herbicide treatment

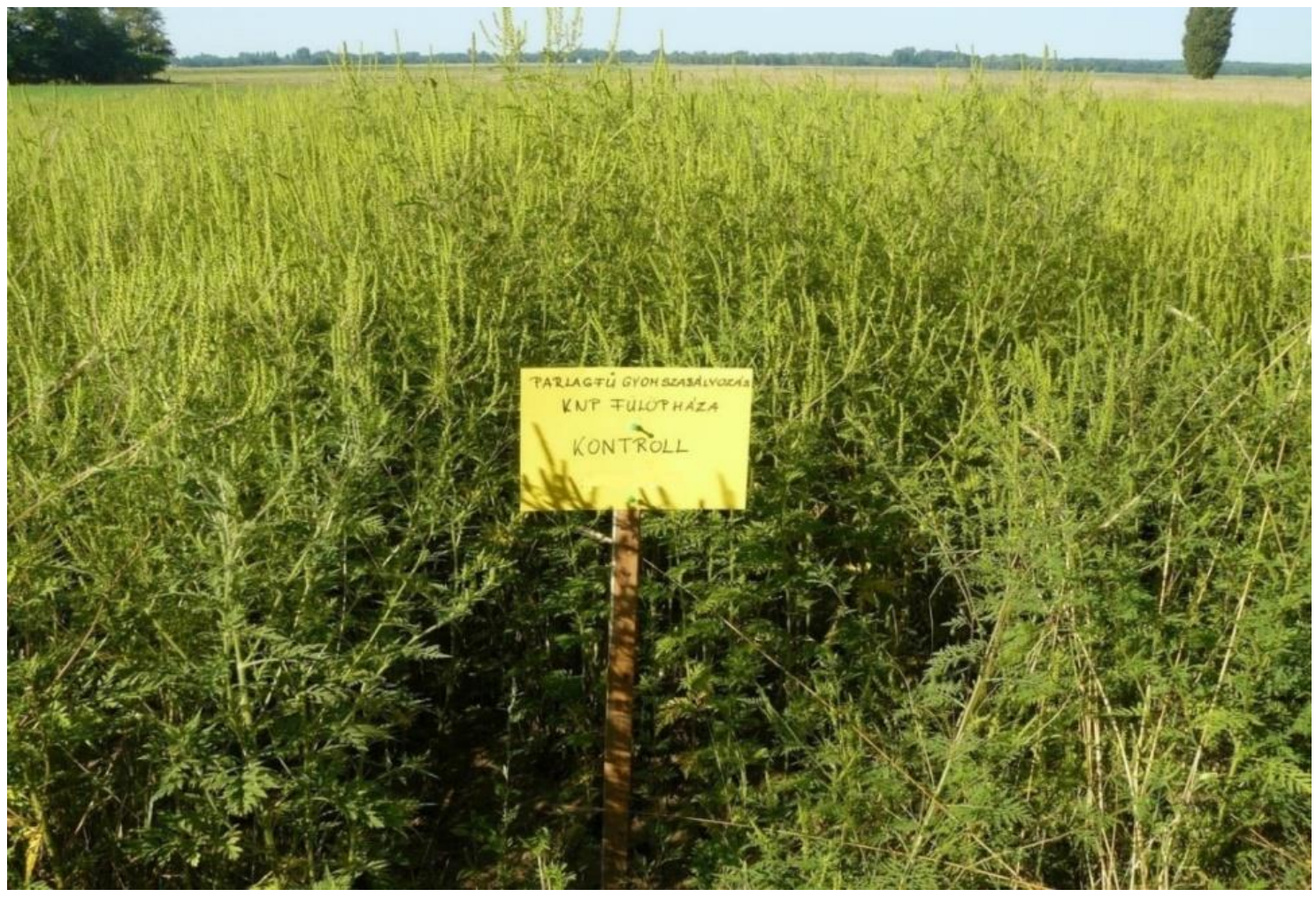

Figure 6. Control area 


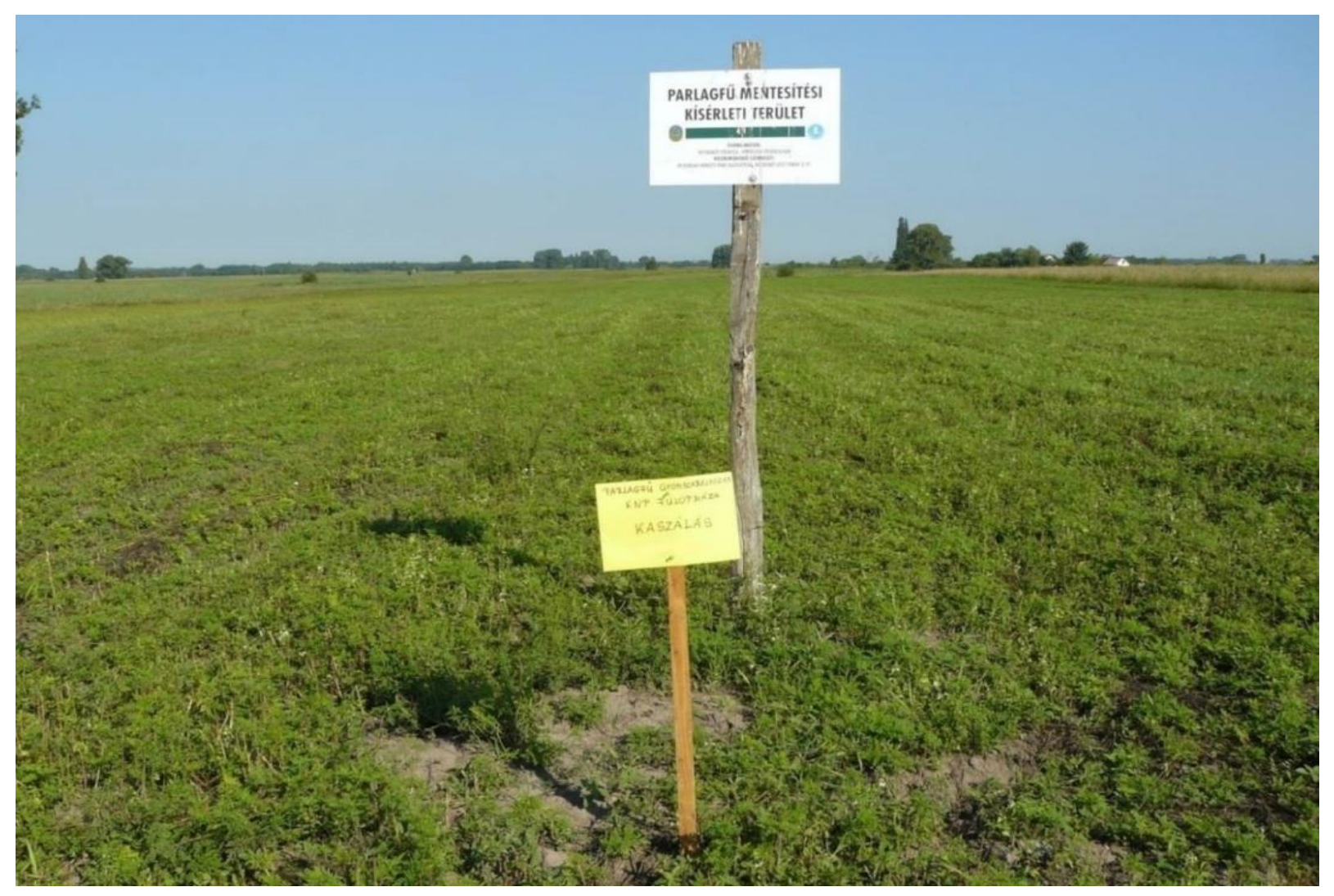

Figure 7. Mowing

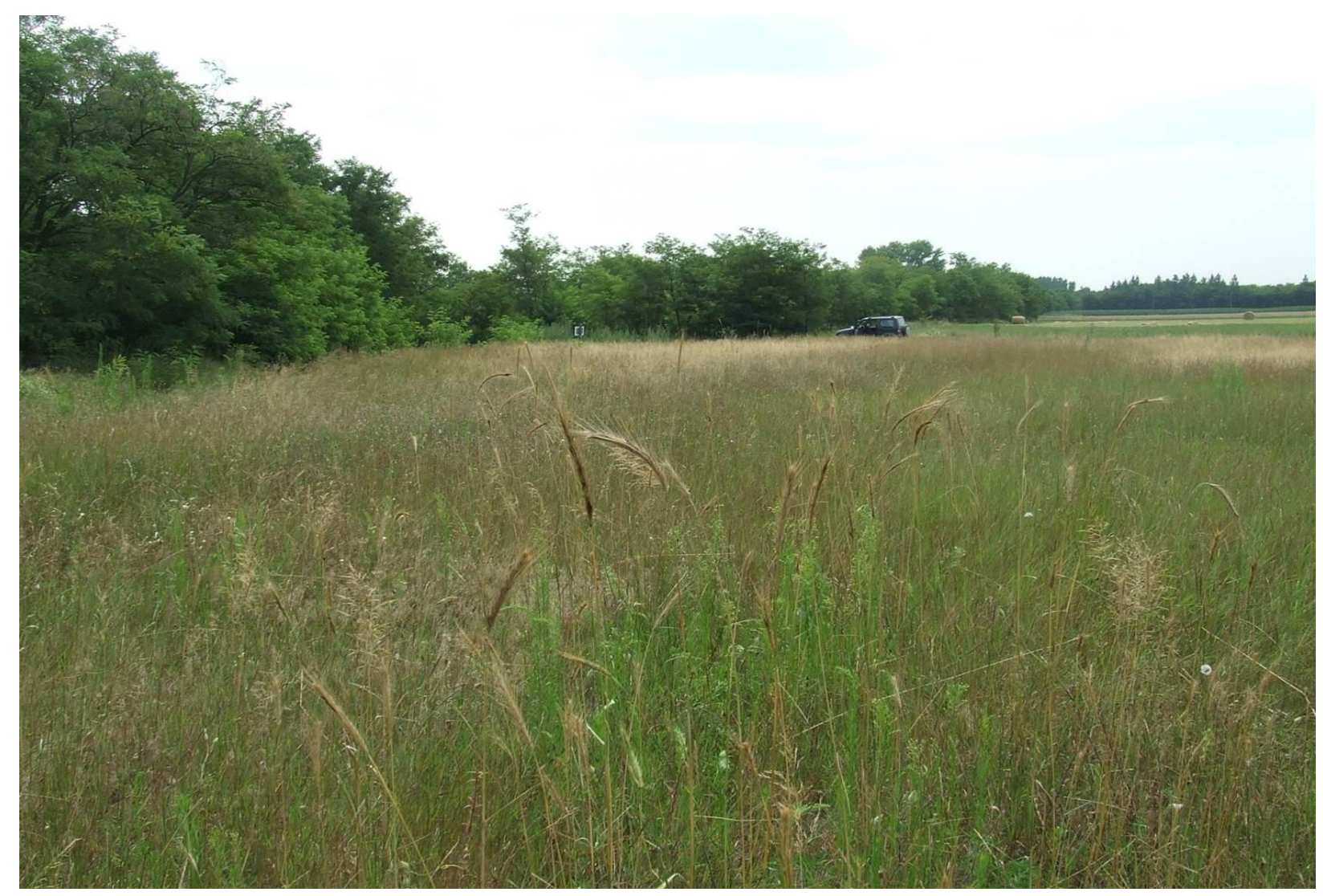

Figure 8. Restoration of the natural plant ecosystem 


\section{Conclusions}

1. Bio-herbicide kills ragweed like a classic herbicide

2. After the bio-herbicide-friendly treatment, the original plant ecosystem is restored

3. The bio-herbicide conserves natural fauna

4. Bio-herbicide is less hazardous to human health and eco-toxicological

5. After mechanical control, the plant should sprout again and the treatment should be repeated at least three times

6. Economic aspects are subject to further examination.

\section{Acknowledgment}

This research is supported by EFOP-3.6.2-16-2016-00006 "The development and enhancement of the research potential at John von Neumann University" project. The Project is supported by the Hungarian Government and co-financed by the European Social Fund.

\section{References}

[1] Benécsné Bárdi G. (2009): Integrált védelem a parlagfüellen. Nem vegyszeres védekezési módszerek. Növényvédelem, Vol. 45. No.8. pp. 459-464.

[2] Deen, W., Swanton, C. J., ,Hunt, L. A. (2001). A mechanistic growth and development model of common ragweed. Weed science, 49(6), 723-731.

[3] Kazinczi, G., Pál-fám, F., Nádasy, E., Takács, A.,Horváth, J. (2013). Allelopathy of some important weeds in Hungary. Plant Protection Society of Slovenia, Zbornik Predavanj in Referatov, 11, 410-415.

[4] Radics L. ,Divéry-Ertsey A., Gál I. (2011): A parlagfű és az ellene való védekezés lehetőségei Agroinform, Vol. 20. No. 4. pp. 40

[5] Reddy, Krishna N., Charles T. Bryson, and lan C. Burke. (2007): Ragweed parthenium (Parthenium hysterophorus) control with preemergence and postemergence herbicides. Weed technology 21.4 982-986.

[6] Smith, M., Cecchi, L., Skjøth, C. A., Karrer, G., Šikoparija, B. (2013). Common ragweed: a threat to environmental health in Europe. Environment international, 61, 115-126. 